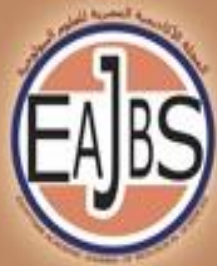

EGYPTIAN ACADEMIC JOURNAL OF
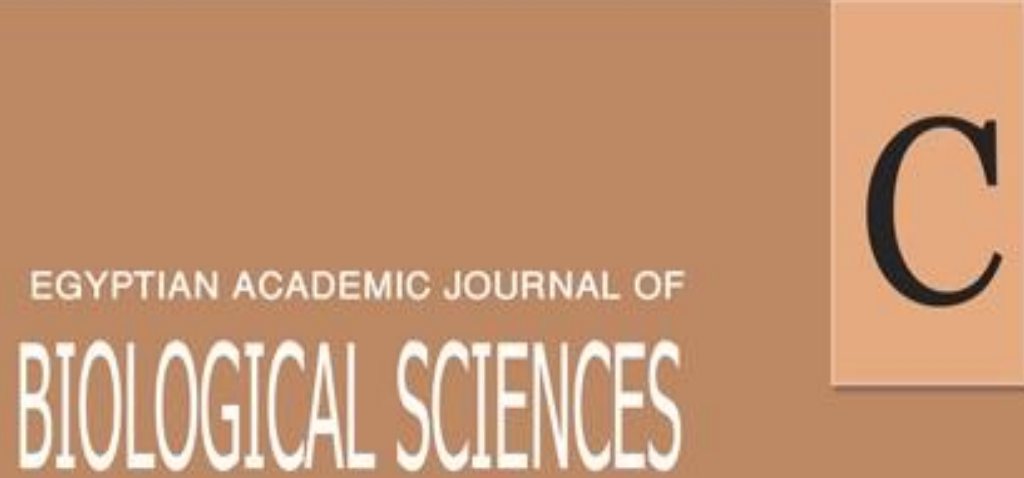

PHYSIOLOGY \& MOLECULARBIOLOGY
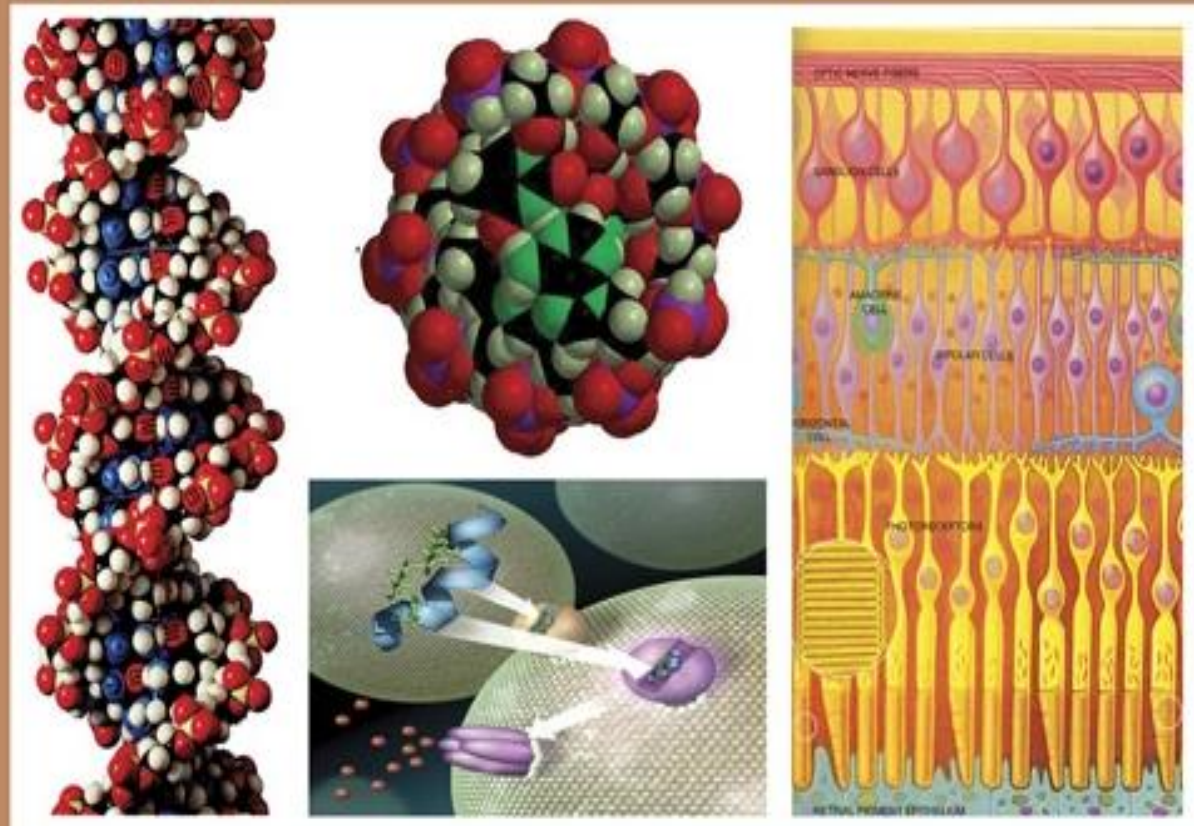

ISSN

2090-0767

WWW.EAJBS.EG.NET

Vol. 14 No. 1 (2022) 
Egypt. Acad. J. Biolog. Sci., 14(1):65-75 (2022)

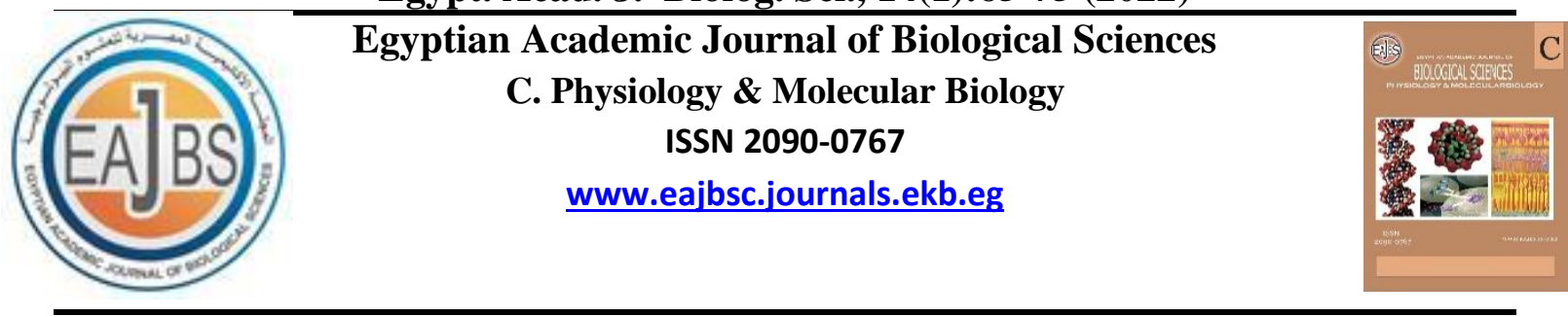

\title{
Epidemiology of Systemic Lupus Erythematosus in Western Algeria. A Multicenter Study of 194 Cases
}

\author{
N.R. Belmokhtar*1-2-; N. Harir ${ }^{1-2}$; K. Zemri ${ }^{1-2}$; K. Kanoun ${ }^{1-2}$; B.M.Bachaoui ${ }^{3}$ and \\ S.T. Hebri ${ }^{4}$
}

1-Biology Department., Faculty of Natural and Life Sciences, University Djillali Liabès of Sidi Bel Abbés, Algeria. Address: 12 Rue Oulhaci Mokhtar. University of Sidi Bel Abbes, Algeria.

2-Molecular Microbiology, Proteomics and Health Laboratory, Faculty of Natural and Life Sciences, Djillali Liabès University of Sidi Bel Abbés, Algeria. Address: 12 Rue Oulhaci Mokhtar. University of Sidi Bel Abbes, Algeria

3-Department of Internal Medicine-Diabetes, Etablissement Hospitalier Universitaire d'ORAN 1 November 1954, Algeria. Address: BP Nº 4166 Ibn Rochd. Oran 31000 Algeria.

4-Department Internal Medicine, University Hospital Centre CHU Dr HASSANI Abdelkader. Sidi Bel Abbes, Algeria. Address: Rue Belahcen Mourad, Sidi Bel Abbes 22000, Algérie

*E. Mail: avril_lavignerockstar@ hotmail.fr

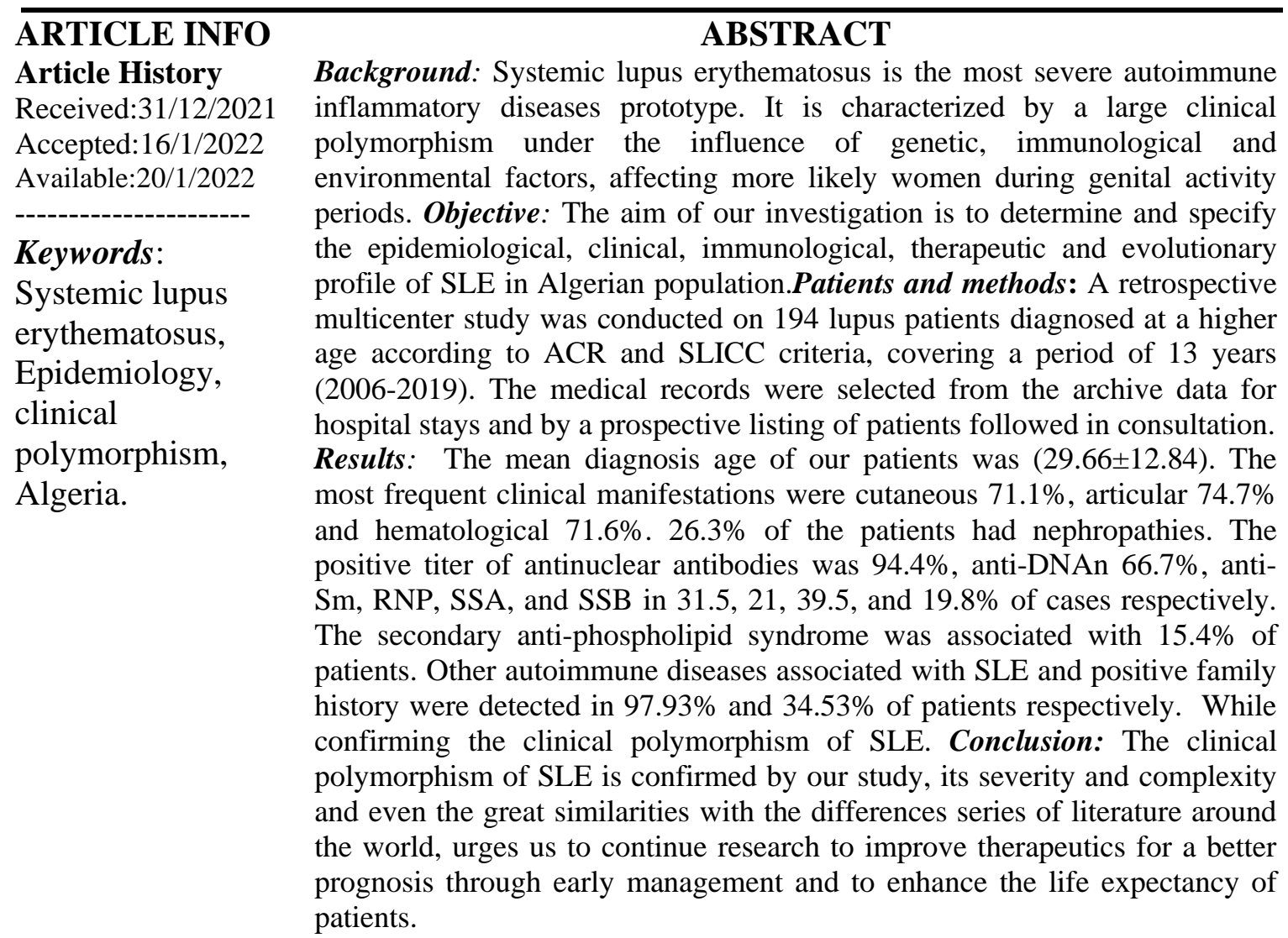




\section{INTRODUCTION}

Systemic lupus erythematosus (SLE) is a chronic disease classified as one of the most serious autoimmune diseases, the precise causes remain unknown and probably heterogeneous (Iliopoulos A, et al.,1996), with a large clinical polymorphism characterized by a multifactorial disruption of the immune system and the production of autoantibodies directed essentially against nuclear antigens (Tan EM, 1989). The disease affects more likely women during periods of genital activity with a sex ratio of 9 females to 1 male (Shlomchik MJ, et al.,2001), but it can also begin in children and the elderly. SLE is a multifactorial pathology depending on a genetic context, immunological, endocrine and even environmental factors contributing to the onset and then the aggravation of the disease (Shlomchik MJ, et al., 2001; Haddouk S et al., 2005). Several series of SLEs have been reported worldwide (Louzir B et al.,2003; Siegle M et al., 1973; Segasothy M et al.,2001). But it is still insufficient in North Africa (Symmons DPM, 1995; El Garf A et al., 1990), especially in Algeria.

The objective of our investigation is to define the epidemiological, clinical, biological, immunological, and evolutionary profile of systemic lupus erythematosus in the Algerian population.

\section{MATERIALS AND METHODS}

This is a retrospective multi-center study of patients diagnosed with SLE between January 2006 and December 2019 at the ORAN University Hospital (EHU), and actively monitored in the internal medicine department. The medical records were selected from the archive data for hospital stays and by a prospective listing of patients followed in consultation. All patients over the age of 16 years were included in the diagnosis of SLE made according to the ACR 1997 criteria and SLICC (Systemic Lupus International Collaborative Clinics) of 2012 (Petri M et al.,2012). Patients under 16 years of age were excluded because they were followed by a different medical team (paediatrics).

A total of 194 patients were included. Causes of exclusion were: patients with less than 4 ACR and SLICC criteria; 26 patients suspected of SLE, records with insufficient data, 09 patients who died during hospitalization.

The standardized data collection included demographic, clinical, biological, 2002 SLICC and 1997 ACR criteria (Hochberg MC, 1997) as well as therapeutic interventions and potential iatrogenic complications. Information on deaths during hospitalization was collected from hospital records and death registers. Given the retrospective nature of the study, the ethnic origin could not be determined since Algerians are generally descended either from Berbers or Arabs, which are the two predominant ethnic groups in Algeria. For associated autoimmune diseases, the criteria for definition were specific to each disease: American-European criteria for GougerotSjögren syndrome (Vitali C et al., 2002), Sydney International criteria for APLS (Vitali C et al.,2002), joint ACR/EULAR criteria for Rheumatoid Arthritis (Aletaha D et al., 2010).

Data were entered and analyzed via SPSS 22.0 (Statistical Package for the Social Sciences, IBM Corporation; Chicago, IL. August 2011) and Excel (®. Qualitative variables were expressed in numbers and percentages, quantitative variables in mean with their standard deviations and/or $95 \%$ confidence intervals calculated according to the normal distribution. In the case of nonnormal distribution, the quantitative variables were described with the median rates.

\section{RESULTS AND DISCUSSION} Characteristics of the Study Population:

Of the 194 patients included, 184 were female $(94.85 \%)$ and 10 were male (5.2\%); giving a female/male sex ratio of 
18.24:1 and a mortality rate of $4.61 \%(n=$ 09 ). The mean age of disease onset was $29.66 \pm 12.84$ years (Extremes: 11-89 years) and the most affected age range was 19-26 years, the mean age at diagnosis was $42.07 \pm 13.85$ years, the most affected age range was 26-36 years. A family history of first-degree autoimmune disease was found in 67 patients or $34.53 \%$ of cases. There was a history of Lupus in 7 cases (3.6\%), Diabetes 20 cases $(10.3 \%)$, high blood pressure 10 cases (5.2\%), DT+ high blood pressure 24 cases $(12.4 \%)$ and 06 patients $(3.1 \%)$ had a family history of other AI diseases (RA, thyroid,). One hundred and ninety (190) patients (97.93\%) had another autoimmune disease: $63.4 \%$ had Anemia, 25.8\% Raynaud's Syndrome, 5.2\% GougerotSjogren, $11.3 \%$ diabetes $1 / 2,17 \%$ high blood pressure, 25.3\% LN (lupus nephropathy), 7.7\% Rheumatoid Arthritis, $10.8 \%$ APLS, $7.2 \%$ Neuropsychiatric systemic lupus erythematosus (NPSLE), $35.6 \%$ had other diseases such as dermatomyositis, Hashimoto's thyroid, psoriasis....etc

\section{Clinical and Biological Characteristics of Lupus Disease:}

The major clinical manifestations observed in the 194 lupus patients during the study period are shown in (Table 1), according to the criteria defined by the SLICC and ACR classification. Patients met an average of 6 criteria (extremes: 414).

The initial manifestations were joint involvement $74.7 \%$, haematological $71.6 \%$, cutaneous $71.1 \%$, pulmonary $35.1 \%$, renal $26.3 \%$, cardiac $9.8 \%$, and central nervous system (CNS/8) involvement $11.3 \%$.

Table 1: Main Clinical features of the 194 systemic lupus erythematosus (SLE) patients in Algeria

\begin{tabular}{|c|c|}
\hline General signs & Patients load (\%) \\
\hline Fever (non-infectious fever) & $18(9.3)$ \\
\hline Asthenia & $74(38.1)$ \\
\hline Weight loss & $37(19.1)$ \\
\hline Anorexia & $18(9.3)$ \\
\hline \multicolumn{2}{|l|}{ Articular manifestation " } \\
\hline Arthritis/ Arthralgias & $145(74.7)$ \\
\hline Dermatological disorders ${ }^{\mathrm{a}}$ & $138(71.1)$ \\
\hline Photosensitivity & $77(39.7)$ \\
\hline Malar rash & $107(55.2)$ \\
\hline Mucosal ulcera & $28(14.4)$ \\
\hline Alopecia not scarring & $41(21.1)$ \\
\hline Renal involvement & $51(26.3)$ \\
\hline Nephrotic syndrome & $02(1)$ \\
\hline Nephropathy class $I^{b}$ & $18(9.3)$ \\
\hline Nephropathy class II ${ }^{b}$ & $02(1)$ \\
\hline Nephropathy class III ${ }^{b}$ & $05(2.6)$ \\
\hline Nephropathy class IV ${ }^{b}$ & $07(3.6)$ \\
\hline RPGN & $08(4.1)$ \\
\hline Acute renal insufficiency & $01(0.5)$ \\
\hline Chronic renal insufficiency & $05(2.5)$ \\
\hline Cardiovascular manifestations & $18(9.3)$ \\
\hline Pericarditis ${ }^{2}$ & $13(6.3)$ \\
\hline Lung damage & $68(35.1)$ \\
\hline Neuropsychiatric ${ }^{\star}$ & $22(11.3)$ \\
\hline Specific digestive impairment & $04(2.1)$ \\
\hline Autoimmune hepatitis & $02(1.0)$ \\
\hline Ocular injury & $05(2.6)$ \\
\hline $\begin{array}{l}\text { Viral infection (EBV, CMV, } \\
\text { Zona) }\end{array}$ & $02(1.0)$ \\
\hline
\end{tabular}

a Definition according to the classification of Systemic Lupus International Collaborating Clinics (SLICC 2012) (Petri M et al.,2012)

${ }^{b}$ Accorging to the 2003 classification of the International Society of Néphrologie and the Renal Pathology Society (ISN/RPS) (Weening JJ, 2004)

RPGN: Rapidly Progressive Glomérulonéphritis; EBV: Eptein-Barr Virus; CMV: Cytomégalovirus. 
A potential triggering factor for the inaugural manifestations of LS was reported in 6 cases (3.09\%): lupus pregnancy in 2 cases, autoimmune hepatitis in 2 cases, an infectious syndrome in 2 cases. Viral type infections (CMV, EBV, Zona) had directly preceded the initial manifestations of lupus.

$$
\text { Concerning dermatological }
$$

disorders, we noted: 107 cases $(55.2 \%)$ of malarial rash, 77 cases of photosensitive lupus lesions (39.7\%), 28 cases $(14.4 \%)$ of oral-nasal ulcers, 41 cases $(21.1 \%)$ had non-scarring alopecia). Among the $26.3 \%$ covering the SLICC criteria for nephropathy, 32 patients had lupus nephropathy of a different class, 08 cases had rapidly progressive glomerulonephritis (RPGN) and 05 cases had severe or endstage chronic renal insufficiency.

The main biological and immunological manifestations are presented in (Table 2). The inflammatory syndrome is very remarkable in our patients, erythrocyte sedimentation rate (ESR) is accelerated in almost all patients (92.79\%), with a mean ESR (1st hour) equal to $59.80 \pm 37.36 \mathrm{~mm} / \mathrm{h}$ and ESR (2nd hour) equal to $88.22 \pm 38.33 \mathrm{~mm} / \mathrm{h}, \mathrm{CRP} \mathrm{C}$ reactive protein-positive in $53.6 \%$ of cases with a mean equal to $18.10 \pm 24.61$. Clinical and biological manifestations are also reported according to the criteria validated earlier.

Table 2: Hematologic Biological and Immunologic Abnormalities of Lupus Patients at Follow-Up by SLICC Criteria

\begin{tabular}{|c|c|}
\hline & $\begin{array}{l}\text { Patients load (\%) } \\
(n=194)\end{array}$ \\
\hline Hematological & $139(71.6)$ \\
\hline Leucopenia $(<4 \mathrm{G} / 1)$ & $39(20.1)$ \\
\hline Lymphopnia ( $<1 \mathrm{G} / 1)$ & $61(31.4)$ \\
\hline Thrombopenia $(<100 \mathrm{G} / 1)$ & $41(21.1)$ \\
\hline Neutropenia & $9(4.6)$ \\
\hline Anemia & $123(63.4)$ \\
\hline Normochromic Normocytic Anemia & $67(34.5)$ \\
\hline Microcytic Hypochromic Anemia & $26(13.4)$ \\
\hline Hypochromic Normocytic Anemia & $8(4.1)$ \\
\hline Normochromic Microcytic Anemia & $6(3.1)$ \\
\hline Hemolytic anemia & $16(8.2)$ \\
\hline Inflammatory Syndrome & \\
\hline Accelarated ESR & $180(92.79)$ \\
\hline Positive CRP & $104(53.6)$ \\
\hline Serum protein electophoresis (SPEP) & \\
\hline Chronic inflammatory reaction & $124(63.9)$ \\
\hline Acute inflammatoryreaction & $36(18.6)$ \\
\hline Subacute inflammatory reaction & $9(4.6)$ \\
\hline PEwithout major features & $25(12.9)$ \\
\hline & $\begin{array}{c}\text { Patients load (\%) } \\
(n=162)\end{array}$ \\
\hline Immunological & \\
\hline Antinuclear antibody $(\geq 1 / 80)$ & $153(94.4)$ \\
\hline anti-dsDNA & $108(66.7)$ \\
\hline anti-Sm & $51(31.5)$ \\
\hline anti-Sm/RNP & $34(21.0)$ \\
\hline anti-Ro/SSA & $64(39.5)$ \\
\hline anti-La/SSB & $32(19.8)$ \\
\hline anti-Histone & $16(9.9)$ \\
\hline anti-Ribosome & $04(2.5)$ \\
\hline anti-Centromère & $03(1.9)$ \\
\hline anti-Nuclésome & $10(6.2)$ \\
\hline anti- SCL-70 & $09(5.6)$ \\
\hline anti-phospholipid (APL) & $25(15.4)$ \\
\hline Hypocomplementemia & $60(30.92)$ \\
\hline
\end{tabular}

ESR : Erythrocyte Sedimentation Rate, CRP : C reactive protein, SPEP : Serum protein Electrophoresisdes; Anti-dsDNA: anti-double-stranded -DNA ;APL: antiphospholipid 


\section{Treatments and Evolution:}

The main drug treatments for lupus received by our patients are presented in (Table 3). Among the 194 lupus cases, the majority of patients had iatrogenic complications, mainly urinary and pulmonary infections. There were also patients with treatment side effects, 10 cases of corticosteroid-induced diabetes, 08 patients with osteoporosis and 04 cases of adrenal insufficiency. Concerning deaths during hospitalization, we noted 09 cases $(4.61 \%)$.

Table 3: Treatments administered to 194 lupus patients:

\begin{tabular}{|l|c|c|c|}
\hline \multicolumn{1}{|c|}{ Treatment } & $\begin{array}{c}\text { Number of } \\
\text { patients }\end{array}$ & $\%$ & $\begin{array}{c}\text { Specific indications } \\
\text { According to organ }\end{array}$ \\
\hline Hydroxychloroquine & 167 & 86,1 & General signs/ Skin \\
\hline Corticosteroid & 179 & 92,3 & Skin/ Joints \\
\hline Oral Corticostroid >15mg/d & 179 & 92,3 & Skin/ Joints \\
\hline IV Corticosteroid therapy & 43 & 22,2 & Kidney/ CNS \\
\hline NSAIDs & 19 & 9,8 & Articular \\
\hline Immunosuppressive drugs & 70 & 36,1 & $\begin{array}{c}\text { Kidney/CNS/ } \\
\text { Articular }\end{array}$ \\
\hline Cyclophosphamide (Endoxan) & 38 & 19,6 & Rein/ CNS \\
\hline Méthotrexate (MTX) & 12 & 6,2 & Articular \\
\hline Azathioprine (Immurel) & 30 & 15,5 & Kidney/joint \\
\hline Mécophénolate mofétil (MMF) & 9 & 4,6 & Kidney \\
\hline Biotherapy (Rituximab/ IVIG) & 21 & 10,8 & $\begin{array}{c}\text { Kidney/ Haematology/ } \\
\text { Joint }\end{array}$ \\
\hline
\end{tabular}

IV: Intravenous; NSAIDs: Non-Steroidal Anti-Inflammatory; IVIG: Intravenous immunoglobulin ; CNS : Central nervous system

Table 4: A comparison of the different clinical and serological manifestations of SLE in Algeria and other international studies:

\begin{tabular}{|c|c|c|c|c|c|c|c|c|c|c|c|c|c|}
\hline $\begin{array}{c}\text { ACR } 1982 \\
\text { Criteria }\end{array}$ & $\begin{array}{l}\text { Our } \\
\text { study }\end{array}$ & \multicolumn{2}{|c|}{$\begin{array}{c}\text { Tunisia } \\
\text { (Louzir B et } \\
\text { a1.,2003; Haddouk S } \\
\text { et a1.,2005) }\end{array}$} & $\begin{array}{c}\text { Morocco } \\
\text { (Bouras } \\
\text { M et } \\
\text { al.,2014) }\end{array}$ & \begin{tabular}{|c|} 
Kuwait \\
(A1- \\
Jarallah K \\
et al.,1998)
\end{tabular} & $\begin{array}{c}\text { Saudi } \\
\text { Arabia } \\
\text { (Alballa } \\
\text { SR, 1995) }\end{array}$ & $\begin{array}{c}\text { Egypt } \\
\text { (E1 Hadidi } \\
\text { KT et } \\
\text { al.,2018) }\end{array}$ & $\begin{array}{l}\text { Lebanon } \\
\text { (Uthman I } \\
\text { et al.,1999) }\end{array}$ & $\begin{array}{c}\text { Europe } \\
\text { (Cervera } \\
\text { R et } \\
\text { a1.,1993) }\end{array}$ & $\begin{array}{c}\text { North } \\
\text { America } \\
\text { (Tan EM } \\
\text { et al.,1982) }\end{array}$ & $\begin{array}{l}\text { Malaysia } \\
\text { (Wang F } \\
\quad \text { et } \\
\text { al.,1997) }\end{array}$ & $\begin{array}{c}\text { India } \\
\text { (Malaviya } \\
\text { AN et } \\
\text { al.,1997) }\end{array}$ & $\begin{array}{c}\text { Brazil } \\
\text { (Chahade } \\
\text { WH et } \\
\text { al.,1995) }\end{array}$ \\
\hline Number of patiens & 194 & 295 & 84 & 129 & 108 & 93 & 1109 & 100 & 1000 & 177 & 539 & 1366 & 685 \\
\hline $\begin{array}{l}\text { Proportion of } \\
\text { women (\%) }\end{array}$ & 94.85 & 91.86 & 85.71 & 88.37 & 90.74 & 90.3 & 89.7 & 86 & $\mathrm{NA}$ & $\mathrm{NA}$ & $\mathrm{NA}$ & NA & 94.45 \\
\hline Mean age attainmant & 29.6 & 30.6 & 29.9 & 31 & 31.5 & 24.4 & 25.8 & 25 & $\mathrm{NA}$ & $\mathrm{NA}$ & $\mathrm{NA}$ & 24.5 & 31 \\
\hline & & & & & & Critères de 1 & $\mathrm{ACR}$ & & & & & & \\
\hline Malar rash & 55.2 & 62 & 57.1 & 67.4 & 43 & 37 & 48.5 & 52 & 58 & 57 & 60.8 & 58.5 & 51 \\
\hline Photosensitivity & 39.7 & 46 & 45.2 & 75 & 48 & 22 & 45.6 & 16 & 45 & 43 & 25.9 & 48 & 47 \\
\hline Mucosal ulcer & 14.4 & 15 & 7.1 & 29.3 & 33 & 17 & 34.5 & 40 & 24 & 27 & 23.7 & 55 & 11 \\
\hline Articular manifestation & 74.7 & 90 & 78.6 & 65 & 87 & 68 & 76.7 & 95 & 84 & 86 & 36 & 85 & 92 \\
\hline $\begin{array}{c}\text { Renal } \\
\text { involvement }\end{array}$ & 26.3 & 56 & 59 & 46.8 & 37 & 61 & 33.1 & 50 & 39 & 51 & 49.5 & 73 & 52 \\
\hline Atteintes neurologique & 11.3 & 14.5 & 14.3 & 5.5 & 23 & 20 & 6.4 & 19 & 27 & 20 & 23 & 27 & $\mathrm{NA}$ \\
\hline $\begin{array}{c}\text { Hematological } \\
\text { disorders }\end{array}$ & 71.6 & 65 & 70 & $\mathrm{NA}$ & 53 & 85 & 55 & 47 & 22 & 59 & $\mathrm{NA}$ & 21 & $\mathrm{NA}$ \\
\hline $\begin{array}{c}\text { Antinuclear } \\
\text { antibody }\end{array}$ & 94.4 & 92 & 97.6 & $\mathrm{NA}$ & 94 & 95 & 96.9 & 87 & 96 & 99 & 69.1 & 98 & 96 \\
\hline Positive anti-DNA & 66.7 & 74 & 75 & $\mathrm{NA}$ & 58 & 90 & 79.3 & 50 & 78 & 67 & 34 & 55 & 47 \\
\hline Anti-Sm & 31.5 & 57 & 36.9 & $\mathrm{NA}$ & 13 & 40 & 22.5 & $\mathrm{NA}$ & 10 & 31 & $\mathrm{NA}$ & 29 & 43 \\
\hline
\end{tabular}

anti-dsDNA: antibody to double-stranded DNA; anti-sm: antibody to sm nuclear antigen; NA: data not available

Our study is the first investigation of SLE in Algeria, it confirms the clinical polymorphism of the disease and its similarity with other series in different regions of the world (Table 4).

SLE is a disease of young women with a peak in the third decade of life. We found a female predominance $(94.85 \%)$, which is similar to several series in the literature where the rate is over $85 \%$ (Borcher AT et al.,2010, Louzir B et al.,2003, Al-Jarallah K et al., 1998, Alballa SR, 1995; Haddouk S et al., 2005), our series illustrated that this predominance supports the hypothesis of endocrine factors involved in the 
etiopathogenesis of Lupus (Haddouk S et al.,2005; Vilarinho $\mathrm{S}$ et al.,1998). The average age of onset was 29.6 years which concords with several findings (Haddouk S et al., 2005; Al-Mekaimi A et al., 1997; Bouras M et al., 2014; Uthman I et al.,1999; Tan EM et al., 1982), a younger average age was found in Saudi Arabia 24.4 years Alballa SR, 1995), Lebanon 25 years (Uthman I et al., 1999), India 24.5 years (Malaviya AN et al., 1997) and 25.8 in Egypt (El Hadidi KT et al.,2018). The main clinical manifestations at the time of diagnosis and follow-up are similar and comparable, regardless of the studied region (Table 4). The clinical studied manifestations were: skin, joint, haematological, renal, cardiovascular, neurological, and pleuropulmonary with some variations according to the studied country.

Photosensitivity occurring during or shortly after sun exposure is frequently observed in our study in $39.7 \%$ of cases, $45.6 \%$ in Egypt (Eh Hadidi KT et al.,2018), 46\% in Tunisia (Louzir B et al.,2003) and 48\% in Kuwait (Al-Jarallah $\mathrm{K}$ et al., 1998). The malarial rash characteristic of SLE is found in $55.2 \%$ of cases, $52 \%$ in Lebanon (Uthman I et al.,1999), 62\% in Tunisia (Vitali $\mathrm{C}$ et al.,2002), 67.4\% in Morocco (Bouras $\mathrm{M}$ et al., 2014), 58\% in Europe (Cervera $\mathrm{R}$ et al., 1993) and 57\% in North America (Tan EM et al.,1982). This percentage is decreased in Saudi Arabia by $37 \%$ (Alballa SR, 1995) and Kuwait by $43 \%$ (Al-Jarallah $\mathrm{K}$ et al.,1998). Mucosal ulcerations noted in our series in Tunisia, Saudi Arabia and Brazil (between 11 and 17\%) (Louzir B et al.,2003; Alballa SR, 1995; Chahade WH et al.,1995) are very low compared to Morocco, Kuwait, Egypt and Lebanon (29 to 40\%) (Bouras M et al., 2014; Al-Jarallah K et al.,1998; El Hadidi KT et al., 2018; Uthman I et al.,1999). Joint manifestations are the most frequent, $74.7 \%$ of the cases in our study, $76.7 \%$ in Egypt (El Hadidi KT et al., 2018), 65\% in Morocco (Bouras M et al., 2014) and 68\% in Saudi Arabia (Alballa SR, 1995), over $80 \%$ in Tunisia, Lebanon, Europe, North America, Brazil, and India (Louzir B et al., 2003; Uthman I et al.,1999; Alballa SR, 1995; Tan EM et al.,1982; Chahade WH et al., 1995; Malaviya AN et al.,1997), but this sign is rarer in Malaysia $36 \%$ (Wang F et al., 1997). Haematological damage is the second most observed manifestation in lupus patients, $71.6 \%$ in our work, Saudi Arabia represents the highest percentage with $85 \%$ of cases (Weening JJ, 2004), 50 to $65 \%$ of cases in Kuwait, Egypt, Tunisia, North America (Al-Jarallah K et al., 1998; El Hadidi KT et al.,2018; Louzir B et al., 2003; Tan EM et al.,1982), India and Europe had the lowest percentage (21/22\%) (Malaviya AN et al., 1997; Cervera R et al.,1993). Lupus nephropathy is variable in the literature according to age, sex, period of recruitment into service, lifestyle and nutrition. It is low equal to $26.3 \%$ in our study and significantly higher in other populations especially in India 73\% of cases (Malaviya AN et al.,1997). Concerning the neurological impairment, the rate was equal to $11.3 \%$ of cases in the Algerian population, $14.3 \%$ in Tunisia (Haddouk S et al.,2005), 5.5\% in the Moroccan population (Bouras $\mathrm{M}$ et al.,2014), 6.4\% in the Egyptian series (El Hadidi KT et al.,2018) and the highest rates were recorded in the Europeans and Asian Indians populations with $27 \%$ of cases (Cervera R et al.,1993; Malaviya AN et al.,1997).

The biological manifestations observed in our work are similar to the data in the literature. Anemia was the most recorded disturbance of the Complete blood count (CBC) and was found in 63.4 $\%$ of the cases, it is most often nonspecific: inflammatory, iron deficiency, or secondary to another pathology associated with SLEs. Normocytic normochromic anemia is noted in $34.5 \%$ of cases, representing the highest percentage, autoimmune hemolytic anemia 
characteristic of SLE was noted in our work in only $8.2 \%$ of cases, leukopenia was observed in $20.1 \%$, lymphopenia $31.4 \%$, thrombocytopenia $21.1 \%$, similar to that noted in the Tunisians (Haddouk $\mathrm{S}$ et al.,2005), Malaysian (Wang F et al., 1997), Lebanese (Uthman I et al.,1999) and Brazilian series (Chahade WH et al.,1995).

On the immunological level, the search for antinuclear antibodies (AAN) is mandatory, they are positive in our work in $94.4 \%$ of cases, $92 \% / 97 \%$ in Tunisia (Louzir B et al.,2003; Haddouk S et al.,2005), 94\% in Kuwait (Al-Jarallah K et al.,1998), 95\% in Saudi Arabia (Alballa SR, 1995), 96.9\% in Egypt (El Hadidi KT et al.,2018), 96\% in Europe and Brazil (Cervera R et al.,1993; Chahade WH et al.,1995), $98 \%$ in Indian population (Malaviya AN et al.,1997).

Positivity of anti-native DNA antibodies observed in $66.7 \%$ of cases similar to that observed in North America (67\%) (Tan EM et al.,1982), and quite close to the percentage in Tunisia, Kuwait, and Europe (Louzir B et al.,2003; AlJarallah $\mathrm{K}$ et al.,1998; Cervera $\mathrm{R}$ et al.,1993, Haddouk $S$ et al.,2005), but significantly higher than in the Lebanese and Malaysian population (Uthman I et al.,1999; Wang F et al.,1997). Another serologic marker is anti-Sm antibody because the currently used ELISA is highly sensitive but lacks specificity, this marker is positive in our study in $31.5 \%$ of cases similar to North America (31\%) (Tan EM et al.,1982), and higher in comparison to the European population (10\%) (Cervera R et al.,1993) without any given explanation.

On the evolutionary level, we noted several drug complications related to the treatments administered by our patients, six cases treated with prednisone presented cortico-induced diabetes $(3.09 \%)$, osteoporosis was found in five patients $(2.57 \%)$.

During the selected study period (2006$2019)$, overall mortality was $4.61 \%(n=09)$ during hospitalization, which represents a lower frequency compared to the one recorded in Tunisia (13\%) (Louzir B et al.,2003) and Brazil 29\% (Chahade WH et al.,1995). The main causes of death were cardiovascular disease (Bartels CM et al.,2014; Abu-Shakra M et al.,2012), renal disease and cerebrovascular accident (CVA or stroke). The use of corticosteroid therapy and immunosuppressive treatment in the management of our patients has proven to be effective in preventing relapses and limiting complications related to lupus disease.

\section{Conclusion:}

Our study is the first retrospective multi-center study on SLE in Algeria. It confirms the clinical polymorphism of this pathology, its seriousness and complexity and even the great similarities with serial differences in the literature around the world urges us to continue research to improve therapeutics in order to improve the prognosis through early management and to extend the life expectancy of lupus patients.

Acknowledgments: We would like to thank the patients for their participation and the staff at the Internal Medicine of the University Hospital of ORAN (EHUO) and the University Hospital of Sidi-belAbbes (CHU-SBA) for their invaluable support, guidance, and educational insight.

Conflict of interest declaration: The authors have declared that there are no potential conflicts of interest with respect to the research, authorship and/or publication of this article.

Funding: The authors received no financial support for the research, authorship and/or publication of this article.

Ethics Approval: The local Ethics Committee of University Hospital has approved our study.

Competing interests: None.

\section{REFERENCES}

Abu-Shakra M, Novack V. (2012). Mortality and Multiple Causes of Death in Systemic Lupus 
Erythematosus - Role of the Death Certificate. Journal of Rheumatology;39(3):458-60

Alballa SR. (1995). Systemic lupus erythematosus in Saudi patients. Clin Rheumatol;14(3):342-6.

Aletaha D, Neogi T, Silman AJ, Julia Funovits,David T. Felson,Clifton O. Bingham III,Neal S. Birnbaum,Gerd R. Burmester,Vivian P. Bykerk,Marc D. Cohen,Bernard Combe,Karen H. Costenbader,Maxime Dougados,Paul Emery,Gianfranco Ferraccioli,Johanna M. W. Hazes, Kathryn Hobbs, Tom W. J. Huizinga,Arthur Kavanaugh, Jonathan Kay,Tore K. Kvien,Timothy Laing,Philip Mease,Henri A. Ménard,Larry W. Moreland,Raymond L. Naden, Theodore Pincus, Josef S. Smolen,Ewa StanislawskaBiernat,Deborah Symmons,Paul P. Tak,Katherine S. Upchurch,Jiř́i Vencovský,Frederick Wolfe, Gillian Hawker (2010). 2010 Rheumatoid arthritis classification criteria: An American College of Rheumatology/European League Against Rheumatism collaborative initiative. Arthritis \& Rheumatism ;62(9):2569-81.

Al-Jarallah K, Al-Awadi A, Siddiqui H, Al-Salim I, Shehab D, Umamaheswaran I, Gaurer S, AlSaeid K, Rajendra Kuar BC, Malaviya A. (1998). Systemic Lupus erythematosus in KuwaitHospital based study. Occasional Series Đ Lupus Around the World.: 5. Lupus; 7:434-8.

Al-Mekaimi A, Malaviya A, Serebour F, Kumar R, Al-Saeid K, Sharma PN. (1997). Serological characteristics of systemic lupus erythematosus from a hospital-based rheumatology clinic in Kuwait. Lupus;6(8):668-74

Bartels CM, Buhr KA, Goldberg JW, Bell
CL, Visekruna M, Nekkanti S, Greenlee RT. (2014). Mortality and Cardiovascular Burden of Systemic Lupus Erythematosus in a US Population-based Cohort. Journal of Rheumatology; 41(4):680-7.

Borchers AT, Naguwa SM, Shoenfeld Y, Gershwin ME. (2010). The geoepidemiology of systemic lupus erythematosus. Autoimmun Review;9: A277-87.

Bouras M, Hali F, Khadir K, Benchikhi H. (2014). Lupus érythémateux systémique: mortalité et facteurs de mauvais pronostic dans une série marocaine de 129 cas. Annales de Dermatologie et de Vénéréologie, 141(2):141-3.

Cervera R, Khamashta A, Font J, Sebastiane GD, Gil A, Lavilla P, Doménech I, Aydintug AO, Jedryka-Goral A, de Ramon E. (1993). The Europeen working Party on systemic Lupus Erythematosus. Systemic lupus erythematosus: clinical and immuno- logic patterns of disease expression in a cohort of 1000 patients. Medicine; 72:113-24.

Chahade WH, Sato EL, Moura JE, Costallat LTL, Andrate LEC. (1995). Systemic lupus erythematosus in Sao Paulo/Brazil: a clinical and laboratory overview. Lupus; 4:100-3.

El Garf A, Salah S. (1990). Systemic lupus erythematosus among Egyptian children. Journal of Rheumatology; 17:1168-70.

El Hadidi KT, Medhat BM, Abdel Baki NM, H Abdel Kafy, W Abdelrahaman, A Y Yousri, D H Attia, M Eissa, D El Dessouki, I Elgazzar, F T Elgengehy, $\mathrm{N}$ El Ghobashy, $\mathrm{H}$ El Hadary, G El Mardenly, H El Naggar, A M El Nahas, R M El Refai, H Allah El Rwiny, R M Elsman, M Galal, $S$ Ghoniem, L A Maged, S M 
Sally, H Naji, S Saad, M

Shaaban, M Sharaf, N Sobhy, R M

Soliman, T S El Hadidi. (2018).

Characteristics of systemic lupus erythematosus in a sample of the Egyptian population: a retrospective cohort of 1109 patients from a single center. Lupus;27(6):1030-8.

Ghedira I, Sakly W, Jeddi M. (2002). Caractéristiques cliniques et sérologiques du lupus érythémateux systémique: à propos de 128 cas. Pathologie Biologie;50(1):18-24.

Haddouk S, Ben Ayed M, Baklouti S, Hachicha J, Bahloul Z, Masmoudi H. (2005). Autoanticorps dans le lupus érythémateux systémique: profil et corrélations cliniques. Pathologie Biologie; 53(6):311-7

Hochberg MC. (1997). Updating the American college of rheumatology revised criteria for the classification of systemic lupus erythematosus. Arthritis \& Rheumatism;40(9):1725-1725.

Iliopoulos A, Tsokos G. (1996). Immunopathogenesis and spectrum of infections in systemic lupus erythematosus. Seminars in Arthritis and Rheumatism, 25(5):318-36.

Louzir B, Othmani S, Ben Abdelhafidh N. (2003). Le lupus érythémateux systémique en Tunisie. Étude multicentrique nationale. À propos de 295 observations. La Revue de Médecine Interne; 24(12):768-74.

Malaviya AN, Chandrasekaren AN, Kumar A, Shamar PN. (1997). Systemic lupus erythematosus in India. Lupus; 6:690-700.

Molina J, Garcia C, Gharavi A, Wilson W, Espinoza L. (1997). Ethnic differences in the clinical expression of systemic lupus erythematosus: A comparative study between African-Americans and Latin Americans.
Lupus;6(1):63-7.

Petri M, Orbai A-M, Alarcón GS, Gordon C, Joan T, Merrill,Paul R. Fortin, Ian N. Bruce, David Isenberg,Daniel J. Wallace,Ola Nived,Gunnar Sturfelt,Rosalind Ramsey-Goldman,Sang-Cheol Bae,John G. Hanly,Jorge SánchezGuerrero,Ann Clarke,Cynthia Aranow,Susan Manzi,Murray Urowitz,Dafna Gladman,Kenneth Kalunian,Melissa Costner,Victoria P. Werth,Asad Zoma,Sasha Bernatsky, Guillermo RuizIrastorza, Munther A. Khamashta, Soren Jacobsen,Jill P. Buyon,Peter Maddison,Mary Anne Dooley, Ronald F. van Vollenhoven,Ellen Ginzler, Thomas Stoll,Christine Peschken,Joseph L. Jorizzo,Jeffrey P. Callen,S. Sam Lim,Barri J. Fessler,Murat Inanc,Diane L. Kamen,Anisur Rahman,Kristjan Steinsson,Andrew G. Franks Jr.,Lisa Sigler,Suhail Hameed, Hong Fang,Ngoc Pham,Robin Brey,Michael H. Weisman,Gerald McGwin Jr.,Laurence S. Magder. (2012). Derivation and validation of the Systemic Lupus International Collaborating Clinics classification criteria for systemic lupus erythematosus. Arthritis \& Rheumatism;64(8):2677-86.

Segasothy M, Phillips PA. (2001). Systemic lupus erythematosus in Aborigines and Caucasians in central Australia: a comparative study. Lupus;10(6):439-44.

Shlomchik MJ, Craft JE, Mamula MJ. (2001). From $\mathrm{T}$ to $\mathrm{B}$ and back again: positive feed-back in systemic autoimmune disease. Nature Reviews Immunology; $1: 147-53)$

Siegle M, Lee Sl. (1973). The epidemiology of systemic lupus. Seminars in Arthritis and Rheumatism, 3:1-54.

Symmons DPM. (1995). Occasional Series: 
Lupus Around the World Frequency of lupus in people of African origin. Lupus;4(3):176-8.

Tan EM, Cohen AS, Fries JF, AT Masi, DJ Mcshane, NF Rothfield, JG Schaller, N Talal, RJ Winchester. (1982). The 1982 revised criteria for the classification of systemic lupus erythematosus: Revised Criteria for Sle. Arthritis \& Rheumatism;25(11):1271-7.

Tan EM. (1989). Antinuclear antibodies: diagnostic markers for autoimmune diseases and probes for cell biology. Advances in Immunology; 44:93-151

Uthman I, Nasr F, Kassak K, Masri A-F. (1999). Systemic lupus erythematosus in Lebanon. Lupus;8(9):713-5.

Vilarinho ST, Lavras-Costallat LT. (1998). Evaluation of the hypothalamicPituitary-Gonadal axis in males with systemic lupus erythematosus. Journal of Rheumatology; 25:1097-103
Vitali C, Bombardieri S, Jonsson R, Moutsopoulos HM, Alexander EL, Carsons SE; Daniels TE; Fox PC; Fox RI; Kassan SS; Pillemer SR; Talal N; Weisman MH. (2002). Classification criteria for Sjögren's syndrome: a revised version of the European criteria proposed by the AmericanEuropean Consensus Group. Annals of the Rheumatic Diseases, 61:554-8.

Wang F, Wang CL, Tan CT, Manivasagar M. (1997). Systemic lupus erythematosus in Malaysia: a study of 539 patients and comparison of prevalence and disease expression in different racial and gender groups. Lupus;6(3):248-53

Weening JJ. (2004). The Classification of Glomerulonephritis in Systemic Lupus Erythematosus Revisited. Journal of the American Society of Nephrology;15(2):241-50. 


\section{ARABIC SUMMARY}

\section{وبائيات الأنبة الحمامية الجهازية في غرب الجزائر. دراسة متعددة المراكز لـ 194 حالة}

بلمختار نعيمة رانيا 1_** ، حرير نورية 1_2 ، زمري خليدة 1_2 ، كانون خديجة 1_2 ، بشاوي بوسهلة 3 ، هبري سيد 4 تاج

1 قسم علم الأحياء ، كلية العلوم الطبيعية و الحيوية ، جامعة جيلالي ليابس بسيدي بلعباس ، الجز ائر. العنوان: شارع

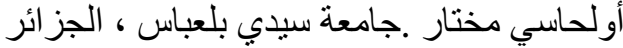

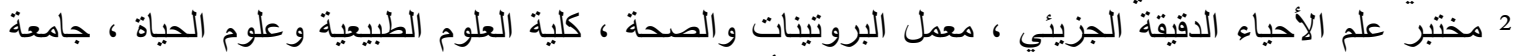

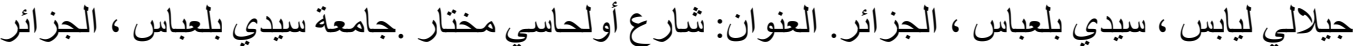

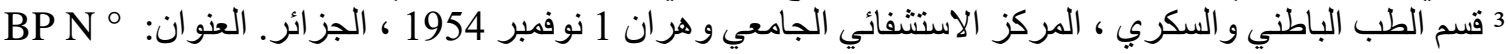
4166 ابن رشد. وهر ان البان والبكري ، 31000 الجز ائر. 4 قسم الطب الباطني ، مستشفى الجامعة ، مركز CHU الدُ الدكتور حسن عبد القادر . سيدي بلعباس ، الجز ائر. العنوان:

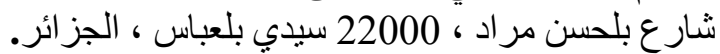

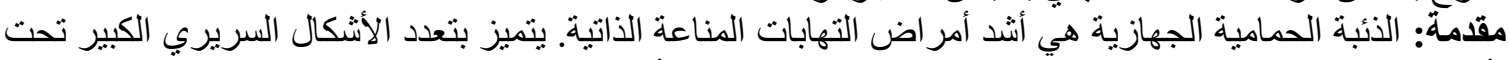

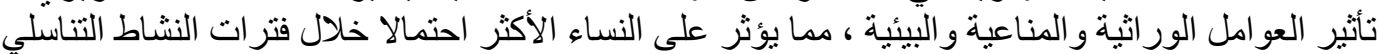

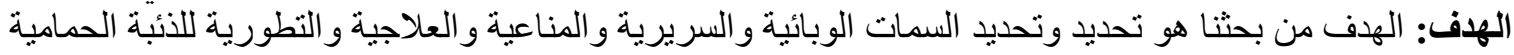
الجهازية في السكان الجزائريين.

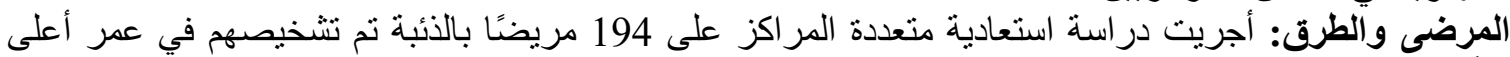
وفقًا لمعايير ALR و ACRC ، تغطي فترة 13 عامًَا (2006-2019). تم اختيار السجلات الطبيةً من بيانات

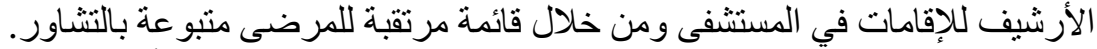

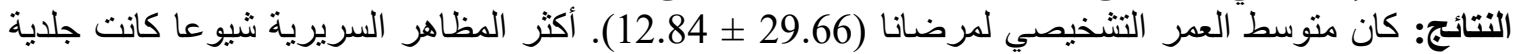

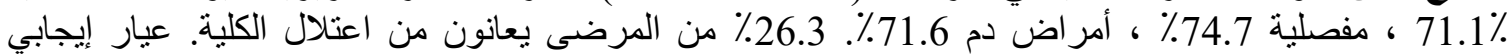

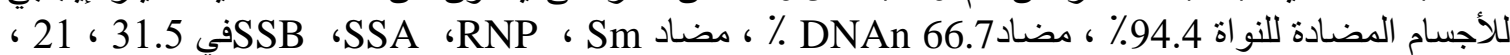

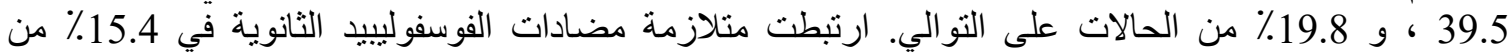

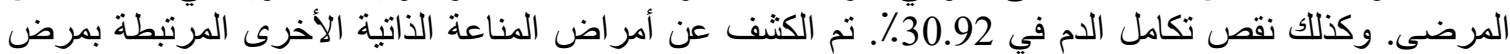
الذئبة الحمر اء و التاريخ العائلي الإيجابي في 97.93\% و 97. 34.53٪ من المرضى على التو الي. مع تأكيد تعدد الأشكال

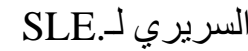

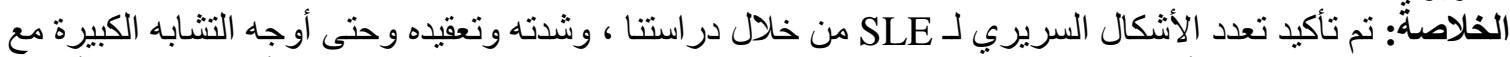

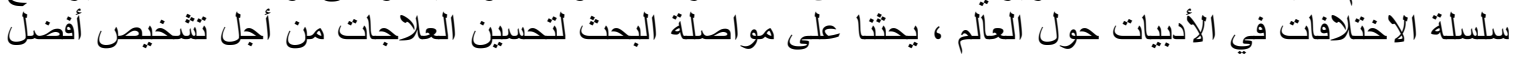
من خلال الإدارة المبكرة وتعزيز منوسط العمر المنوقع لمرضى الأنئة. الكلمات المفتاحية: الذئبة الحمامية الجهازية ، الوبائيات ، تعدد الأشكال الإكلينيكي ، الجز ائر 